\title{
Sites to Remember: Performing the Landscape in Cultural History
}

\author{
Janys Hayes \\ University of Wollongong, Wollongong, Australia
}

\begin{abstract}
This paper aims to compare and contrast two site-specific performance productions, both designed to grapple with processes of cultural remembrance, whilst also operating as successful tourist attractions. The narratives encompassed by both productions revolve around shared Australian histories, for audiences attracted by place and what it is able to represent. Re-enactments of past events call into the present a consideration of what still remains, with both shows enabling new subjective interpretations of earlier times. The defining difference between the two, however, rests in the context of each performance, in the one case as a commodification of heritage and in the other case as the desire to produce an artistic yet popular theatrical product. Ballarat's, Sovereign Hill's light and sound show, Blood on the Southern Cross celebrates and commemorates, in mega-spectacle style, the Eureka Stockade, one of Australia's key historical events. Using a mechanised display of the original goldmining site of the Eureka rebellion, the performance is operated by computers with video-projection, multi-phonic sound, and moving model forms, with audiences moved around the massive site on transporters. The Piccolo Tales, a contrasting performance most notably in terms of size, unfolds the history of Kings Cross, through its setting in the miniscule iconic Piccolo Bar, in one of the tiny side streets of Sydney's bustling and densest suburb. This paper encompasses an investigation of how the cultural inscriptions of the two specific sites interweave with the performance styles, materials, political and social positioning of the works. Previous performance studies examining site-specificity are utilised, including the author's analysis of particular festival performances as “place-making” (Hayes, 2012, 2013). Smith's (2009) model of “signposts” is used to consider acting within site-specific productions in a new light, whilst both performances are more completely analysed through Schneider’s (2011) concept of incomplete pasts forming “cycles of memory”.
\end{abstract}

Keywords: cultural history, historical re-enactments, memory, place-making, site-specific performance, Sovereign Hill, The Eureka Stockade

\section{Introduction}

The definitions of site-specific performance are many, ${ }^{1}$ some emphasising the negative, that the site-specific occurs in "non-theatre locations" (Wilkie, 2002, pp. 140-160), whilst other definitions emphasise

Janys Hayes, Doctor, Lecturer in Theatre and Performance, Faculty of Law, Humanities and the Arts, University of Wollongong.

${ }^{1}$ Seminal texts on site-specific performance emerging from theatrical as well as visual art practices include: Nick Kaye (2000), Site-Specific Art: Performance, Place and Documentation; Miwon Kwon (2002), One Place After Another: Site-Specific Art and Locational Identity; Gay McAuley (2006), Unstable Ground: Performance and the Politics of Place; Mike Pearson (2010), Site-Specific Performance; Joanne Tompkins and Anna Birch (2012), (Eds.), Performing Site-Specific Theatre: Politics, Place, Practice. 
the process, as in Nick Kaye's definition that, the site-specific "articulate(s) exchanges between the work of art and the places in which its meanings are defined” (2000, p. 1). Whilst Mike Pearson claims that definitions of site-specific performance "remain slippery" (2010, p. 7), the many uses of site-specific work have burgeoned, offering engagements with particular communities, engagements with specific histories and politics, and aesthetic engagements with particular physical features, whether natural or manmade. ${ }^{2}$

Used within festival settings site-specific performance offers possibilities of popular entertainment, attracting crowds and demonstrating well-recognised performative techniques that are able to unite communities in a sense of belonging and place. $^{3}$ Yet in a correspondingly oppositional process site-specific performance is able to unsettle and disturb, defamiliarising audiences with known places, offering creative disjunctions between place and performance (Tompkins \& Birch, 2012, p. 1).

For this paper I wish to highlight Jen Harvie's insights that site specific performance has the ability "to explore spatial and material histories and to mediate the complex identities these histories produce" (Harvie, 2005, p. 44). She pinpoints location as having a powerful ability to trigger memory, "helping to evoke specific past times related to the place and time of performance and facilitating a negotiation between meanings of those times” (Harvie, 2005, p. 42). The elicited memories in these circumstances do not require a specific text or set of words (although that too is possible) to be activated but rather the place or materials in the place produce a "ghosting"4 of a previous time that is intuitively encountered; memory has a role in developing attachments to a site. The meanings engendered for any audience are not necessarily fixed. Phrases such as audiences having “creative agency” (McAuley, 2007, p. 9), or being “co-creative” (Turner, 2004, pp. 373-390) in site-specific performance or valuing site-specific performance "through and in interaction" (Pearson, 2010, p. 13) with the site suggest that this type of performance needs to be viewed always within the complex web of relationships that are stimulated.

This paper sets out to interrogate two differing Australian site-specific performance productions in relation to processes of cultural remembrance. Blood on the Southern Cross is described in its publicity as a "spectacular multi-million dollar sound and light show" and with its weekly evening performances across each year since its inception in 1992 (Sikora, 2003, p. 15) sits clearly within the broad spectrum of popular entertainment. The other site-specific production, Piccolo Tales, is now in its second year of production and whilst being funded through a community grant from the City of Sydney, ${ }^{6}$ has arisen from a more theatrically driven incentive. Both are concerned with the past and through the overlay of each specific site, one outdoors and one indoors with the scenography of the performances, both honour distinctly localised Australian heritages. The complexity of the interpenetration of the narratives from the past with the present for the viewing audiences is apparent, with Blood on the Southern Cross set and performed within a theme park, Sovereign Hill, a highly successful Victorian state tourist venue, simulating life on the Ballarat gold fields in the mid-nineteenth century. Blood on the Southern Cross replicates the story of the Eureka Stockade, a pivotal set

\footnotetext{
${ }^{2}$ Gay McAuley specifies three distinct categories of what she terms “site-based” performance in Gay McAuley (2007), Local Acts: Site-Specific Performance Practice, Introduction, About Performance, 7, 7-11.

3 See Janys Hayes (2012), An Issue of "Place”: Circus WOW, Women of Wollongong's Community Circus, in Gillian Arrighi and Victor Emeljanow, ed., A World of Popular Entertainments: An Edited Volume of Critical Essays, pp. 163-175; Janys Hayes (2013), Reframing Tradition: Le Quy Duong’s Festival Theatre, Popular Entertainments Studies, 4(1), 95-109.

${ }^{4}$ Often references to "the ghost and the host" are applied to site-specific performance descriptions. See Michael Cohen (2007),

Tracing New Absence: Events for Place-Making and Place-Faking, About Performance, 7, 189.

5 See from http://www.visitballarat.com.au.

${ }^{6}$ Interview Vashti Hughes 29 Jan 2016.
} 
of events in the creation of Australian democracy. However, the true site of the Eureka Stockade is not within the Sovereign Hill park, but rather several kilometres to the north. The notion of site in Blood on the Southern Cross through emulation is inherently ambiguous. In Piccolo Tales the site is highly emblematic within the performance, with the Piccolo Bar being one of the oldest and singularly owned cafes left in what is now the densest populated suburb in Sydney. The uncertainty in the borders between site and performance or "host and ghost" ${ }^{, 7}$ in this production stems from the performance of Vittorio Bianchi, the 81 year old owner of the cafe whose presence, playing a cafe patron, within the production, skews any separation between the superimposition of the performed narrative about the past and his cafe. Piccolo Tales thus gives a strangely abstruse voice to the passing of the earlier avant-garde world of Kings Cross through a parade of characters who visited or lived close to the tiny Piccolo Bar, with Bianchi’s flamboyant presence signalling that some of the old "Cross" is still surviving.

\section{Blood on the Southern Cross $^{8}$}

To set the staging of Blood on the Southern Cross, which occurs on most evenings throughout the year, travelling across the 64 acre property of the Sovereign Hill outdoor museum (Sikora, 2003, p. 15), it is necessary first to sketch the historical milieuin which the production takes place. Sovereign Hill recreates Ballarat's goldrush years, from 1851 when gold was first discovered there, to a decade later after thousands of prospectors from across Australia and internationally moved to seek their fortune on Ballarat's plains. The outdoor museum exhibits miners' tents and diggings, constructing a creek where gold is panned, whilst a dusty main road with horse-drawn carriages, colonial soldiers, historically fashioned shops and their keepers, winds from the top of a hill where an underground mine shaft dominates the surroundings. Blood on the Southern Cross begins at twilight, so that the museum setting becomes the immersive grounds for the opening of the action. Before entering the site an educational video in an indoor auditorium informs the audience of the outcomes of the Eureka Stockade. The show utilises sound, lights and voices of characters technically masterminded by computers, video projectors, a multi-phonic sound system, thousands of lights, and 10 metre tall lighting towers, as the audience either walks or is carried in articulated transporters across the site (Sikora, 2003, p. 15). A principal narrative voice pre-empts the action with historical information at each of the major settings.

The audience walks in the dusk from the auditorium to the first location in the show, at the Red Hill Gully digging, and is plunged back to1854. In the fog and partial light we hear and see how the goldfields are full of uncertainties, physical dangers and discontents. Miners, living in impoverished conditions, and mining through unsafe practices enter into disputes with the authorities, due to the gold taxes being imposed on them by the government. Each miner is required by law to hold and renew a monthly gold licence, a tax imposed on all, whether each miner finds gold or not. Miners without licences are heavily fined. We hear licence hunts being carried out, with miners galloping away to evade police chases. We hear, through resonating sounds, voices and directed lights, other miners having to climb up and down faulty and dangerously built mining shafts to display their licences. The place we are in is integral to the overall effect of pitting the plight of the miners against what is displayed as an often violent police force.

\footnotetext{
7 See Mike Pearson (2012), Staging “The Persians” with the British Army, in Joanne Tompkins and Anna Birch, (Eds.), Performing Site-Specific Theatre: Politics, Place, Practice, p. 70.

8 The author viewed Blood on the Southern Cross on 28 December, 2015.
} 
For the second location, the trolley-like transporters take the audience to an outdoor auditorium, named as the Free Trade Hotel, from which a vista of the historically crafted Eureka diggings, covering a valley and a distant hill can be seen, as shutters on the "hotel” open. The view is so breathtakingly beautiful, under the stars, lit fantastically, and covered in foggy smoke that the child seated behind me on the night I was in the audience piped, “Mummy? Is it a picture?” From this vantage point the events of Eureka unfold through spectacularly lit models of staged locations with special effects, whilst voiced characters reveal the narrative.

The historical facts of the Eureka Stockade incorporated into the production are as follows. The Eureka Stockade, which took place on 3 December 1854, is named after a rebellion of miners, who built a wooden stockade structure to defend themselves against the colonial government forces with whom the miners were in conflict. The colonists in power introduced in the production include Lieutenant Governor of Victoria, Hotham, who took up his appointment in June 1854 in Melbourne and was a stern enforcer of the licensing system. ${ }^{9}$ Ballarat Goldfields' Commissioner Robert Rede is also represented in the production, moving to Ballarat in May $1854^{10}$ and becoming increasingly hostile with the miners there after a miscarriage of justice. The production suggests that Rede became humiliated after not being able to stop angry miners from burning down the Eureka Hotel, but in retribution punished a group of miners for the fire when they were not necessarily the guilty parties. Rede fuels the growing agitation of the miners, sending the 12th Regiment of Foot to the area, resulting in an ambush by miners who steal a load of rifles. Rede is depicted as being responsible for the December 3 attack on the stockade.

The narration, special effects, lights and sound bind the performative action for this history, as we, the audiences remain statically seated. The two-storey Eureka Hotel bursts into flames and later a downpour of rain, which splashes slightly on the audience, falls across the diggings. During the battle we are caught in the crossfire of gunshots, which resound about our heads and a huge cart rolls towards us bursting into flame, causing gasps from the audience. The visceral nature of the production, where groans from the battle of wounded men and bursts of gunfire vibrate bodies, smoke is smelt, rain felt and lights blind, engulfs the viewers in an affective, empathetic involvement.

Peter Lalor is the only character within the production to physically appear, in comparison to all others who are met through voiceovers. Lalor, first appears as a larger-than-life projected figure on an aqua screen, ${ }^{11}$ at a famous gathering of miners at Bakery Hill after the burning of the Eureka Hotel and the imprisonment of three miners for the offence. Speaking to over 12,000 miners Lalor urges them to burn their licences and raises the Southern Cross flag, white stars and cross on a blue background, not the British flag, in defiance of the colonial rule. At the second meeting where Peter Lalor again speaks on 30 November there are fewer miners, approximately 500, who again burn licences and here Lalor makes a pledge to the Southern Cross flag, "We swear by the Southern Cross to stand truly by each other to defend our rights and liberties"12 After the events of the Eureka Stockade battle, viewed from the Free Trade Hotel, the subsequent trial for treason of 13 miners

\footnotetext{
${ }^{9}$ See B. A. Knox, "Sir Charles Hotham (1806-1855)", Australian Dictionary of Biography, National Centre of Biography, Australian National University from http://adb.anu.edu.au/biography/hotham-sir-charles-3803/text6027.

${ }^{10}$ See Weston Bate, "Robert William Rede (1815-1904)”, Australian Dictionary of Biography, National Centre of Biography, Australian National University from http://adb.anu.edu.au/biography/rede-robert-william-4457/text7263.

11 See Blood on the Southern Cross from http://www.visitmelbourne.com/Regions/Goldfields/Things-to-do/History-and-heritage/Gold-rush-history/Blood-on-the-SouthernCross.aspx.

12 See Ian Turner, “Peter Lalor (1827-1889)”, Australian Dictionary of Biography, National Centre of Biography, Australian National University from http://adp.anu.edu.au/biography/lalor-peter-3980/text6289.
} 
including Lalor in Melbourne in which all the miners are acquitted, is related by voiceover, as the audience is moved from the modelled diggings back into the Main St. of Sovereign Hill by the transporters. An actor now plays Lalor, as a Member of Parliament for Ballarat, reciting from the balcony of the United States Hotel in the Main St. of Sovereign Hill, down to the now standing audience in the street below. Lalor's passionate words to Parliament are of representation of miners' rights, justice, democracy and the Southern Cross flag.

The battle between miners and soldiers and police, known as The Eureka Stockade is the only civic battle fought in Australia's history. Two hundred and seventy six men, soldiers and police attacked 150 or so sleeping miners in the early morning of a Sunday and within twenty minutes 22 diggers were dead with three soldiers also being killed. On hundred and twenty diggers were arrested for this uprising and 13 sent to trial for treason with a jury finding them not guilty (Sikora, 2003, p. 15). The outcomes, with the ending of gold licences, with the establishment of the Electoral Act of 1856 in which all white men gained suffrage including parliamentary representation for the miners, places Eureka, as depicted, as a key turning point in Australian history in the development of the country's democracy.

\section{The Remains of Eureka}

In her seminal work on re-enactments in performance Rebecca Schneider considers that

Most living history events ... are neither framed (or reframed) as art nor do they pretend to anything artistic preferring instead the "authentic” and the "real.” Rather, living history events ... occur as "popular pastime” or "heritage activity” ... (Schneider, 2011, p. 13)

The 300 or so people attending Blood on the Southern Cross when I was present were rugged up for the evening, for an outdoor experience, rather than for the theatre or an evening of art. This was a night to experience Australian history. The popularity of the site is attested to by its economic figures. Sovereign Hill is the premier tourist site in Victoria, netting \$228 million dollars of activity per year to Ballarat and thus to Victoria, and creating 1,442 full-time, part-time and casual jobs. ${ }^{13}$ Natalie Sikora notes that by the middle of 2003 over one million people had already viewed Blood on the Southern Cross (Sikora, 2003, p. 15). The show also attracts busloads as school outings, as all Victorian students study the cause and effects of the Eureka Stockade. The question that Schneider poses in relation to re-enactments is "if time (re)turns. What does it drag along with it?” (Schneider, 2011, p. 2). Schneider cites Foucault in understanding that history itself is a staged set of events through which categories of knowledge and modes of knowledge production are historicized (Schneider, 2011, p. 18). She suggests that the deliberate performing of historical events is already "a matter of reiteration" (Schneider, 2011, p. 32). The point here is that our memories of history are always negotiations that we make with the past. The past and the present intermingle through the re-enactment, and what remains or what the audience is engaged with is an "incomplete past" (Schneider, 2011, p. 33). The reverberations of the past carry interpretations of history that resonate in the present. Schneider presents these as "cycles of memory" (Schneider, 2011, p. 32) enabling fresh reconsiderations of past events. In this case, the events of the Eureka Stockade may not be totally finished but rather are part of an ongoing history, for Australia as yet is still not a republic, still has no other flag apart from the one rejected throughout the Eureka events. The popularity of the show attests to its ongoing reverberation in Australian considerations of our national identity. The image of the

\footnotetext{
${ }^{13}$ See “Sovereign Hill Victoria’s Most Valuable Tourist Icon” from http://www.premier.vic.gov.au/sovereign-hill-victoria’s-most-valuable-tourist-icon.
} 
true-blue Aussie being anti-authoritarian, outspoken, rebellious, is inherent in the performance and is still a celebrated notion. The win for the "little guy" or "working man" is another part of the narrative that also resonates in popular culture.

Concomitantly, the performance, as a "cycle of memory", also produces aspects of history that have been erased or dismissed. Blood on the Southern Cross has the ability to alter memories about the Eureka Stockade. I was aware that two new exhibitions had been added to the Sovereign Hill exhibition since I had last been there in 2006. Firstly a Chinese camp had been added in the diggings by the river and a Chinese joss house. As well, there was an exhibition about the Wadawarrung people, indigenous Australians, and their participation on the goldfields from 1851-1871. In Blood on the Southern Cross there is no mention or appearance of Chinese or aboriginal people on the Ballarat goldfields, yet the Sovereign Hill Education website for secondary students has two pages citing that 40,000 Chinese were on the goldfields by $1857^{14}$ and there is clear evidence that aboriginal people were active in many ways on Ballarat's goldfields. ${ }^{15}$ The Chinese Heritage Interest Network $^{16}$ supplies even clearer figures. 10,000 Chinese migrated to Ballarat and they represented a quarter of the people on the Ballarat goldfields. The lack of Chinese or aboriginal presence within Blood on the Southern Cross was strangely offset by the principal MC, on the evening I viewed it being a young woman of Chinese descent. Her role was to direct the audience to the various sites, on and off the transporters, and to announce the end of the show. Her English was often unclear. I wondered if her presence was a deliberate token gesture to the lack of Chinese within the show, the highly digitalised production effects perhaps costing too much to alter substantially to include new elements. This is only a surmise and the historical "remains" of Eureka in Blood on the Southern Cross are demonstrably male and white.

\section{Piccolo Tales $^{17}$}

Piccolo Tales in contrast to the enormous Blood on the Southern Cross production is a three-person comedic romp in a tiny, restricting space. Australian Stage has reviewed Piccolo Tales concluding "The piece is all about the sense of place and this spectacularly site specific play is enhanced by the staging of this half century saga in and around the property of the Piccolo Bar”. ${ }^{18}$ Piccolo Tales was voted in the Sydney Morning Heralds' top ten theatre moments for 2015 with a revue from Jason Blake that enthuses, "We don't see much in the way of genuine site-specific theatre in Sydney and what we do see usually pays lip service to the concept. Piccolo Tales is the real deal: a work that springs from the location it is performed in”. ${ }^{19}$ Written by Vashti Hughes, directed by James Winter, with the music composed by Ross Johnston, the show's notoriety has been won through the performance of 81 year-old Vittorio Bianchi in his own iconic cafe. It "is a love letter to Kings Cross”,20 a bawdy, cabaret-styled, journey across six decades of inner city musings. At one level, through its enactment in the Piccolo Bar, it operates as a reinstatement of cafe life as a hub of significance. Yet at another

\footnotetext{
${ }^{14}$ See from http://education.sovereignhill.com.au/media/uploads/SovHill-chinesesballarat-notes-ss1.pdf.

15 See Fred Cahir (2012), Black Gold: Aboriginal People on the Goldfields of Victoria 1850-1870.

16 See Irene Scott, “The Chinese in Ballarat”, Chinese National Heritage Interest from

http://chinese-heritage.tripod.com/Chinese\%20in\%20Ballarat.htm.

17 Piccolo Tales by Vashti Hughes, composer Ross Johnston, Piccolo Cafe, Kings Cross, Sydney, 2015\&2016. The author viewed Piccolo Tales on 24 Feb. 2015.

18 See Richard Cotter (2016 March 18), “Review, Sydney: Piccolo Tales/Vashti Hughes”, Australian Stage from http://www.australianstage.com.au/201603177690/reviews/sydney/piccolo-tales-\%7C-vashti-hughes.html.

19 Jason Blake (2015 February 20), “Revue: Piccolo Tales Set in the Heart of its Inspiration”, Sydney Morning Herald from http://www.smh.com.au/entertainment/theatre/review-piccolo-tales-set-in-the-heart-of-its-inspiration-20150220-13kkad.html.

20 See Cotter, (2016 March 18), "Review, Sydney: Piccolo Tales/Vashti Hughes”.
} 
level the show demonstrates a reflective nostalgia for all that is passing, as inner suburbs of Sydney become swallowed in homogenous, and fast-living developments. The ebullient celebratory style of the performance offers what Joseph Roach clearly articulates when he states that performance can "concentrate the complex values of a culture with an intensity that less immediate transactions cannot rival” (Roach, 1985, p. 11).

Only ten patrons can fit into the Piccolo Bar to watch Piccolo Tales, ten more sit on the street pavement in what is termed as "al fresco"21 seating, and another ten are asked to bring their own chairs or rugs and watch from the park opposite the cafe where they are provided with WIFI headphone connections to the show. The action moves inside, outside to the footpath, the road, across to the park. Hughes is the lynchpin of the entire piece, capturing a parade of characters, portrayed as coffee-seekers or passers-by and emblematic to each decade via the stock trade of popular theatre. Parody, physical mimesis, bawdiness, song and dance, cabaret, all are recognisable tools in Hughes' repertoire. Intertwined through this range of characters, is Hughes' depiction of Bianchi as the proprietor of the Piccolo Bar. Hughes creates a loving, fun-filled poke at Vittorio Bianchi's irascibility, while he, the true proprietor, lounges in his window seat, grumbling, interrupting and singing. In a review for The Sydney Morning Herald, Bianchi, speaking of his role quips:

I'm sitting over there [in the window], interjecting. I'm the heckler. I say, “where's my coffee?”, and "this coffee is shit” and "oh, why don't you shut up we're sick of hearing all this rubbish”. Then in the end we get together and sing a beautiful song. 22

Vittorio Bianchi started work at the cafe, as a young Sicilian immigrant and in the 1970s trained as an actor at Hayes Gordon's then new Ensemble Studio, situated just north of the Sydney Harbour Bridge. Juggling both his cafe hours and his acting classes he gave up acting after ten years in which he complained he never was given more than a line. Later he became the MC for Cabaret Conspiracy performing at the Garibaldi cafe also in Kings Cross. ${ }^{23}$ It is his flamboyant, outspoken presence as well as the all night opening hours in the early years of the cafe that has attracted artists, strippers, bohemians, drag queens, actors, film stars and celebrities to the Piccolo Bar. The photos of his famous patrons are on the walls, their names dropped in the banter in Piccolo Tales between Hughes and Bianchi.

In an interview with Vashti Hughes she outlined the main characters in each of the portrayed decades. ${ }^{24}$ Abe Saffron, nightclub owner, property dealer and underworld businessman provides one of more sexually audacious scenes set in the 1960s. Hughes plays Mr. Sin, as he was called, with his trousers down around his ankles receiving sexual favours from a waitress. Rosaleen Norton also appears in that decade, nicknamed "The Witch of Kings Cross” and as an occultist artist, she epitomises the bohemian side of The Cross in the show. Adrag queen from the Les Girls revue from the 1970s appears, Ayesha, a friend of Vittorio's who still visits the cafe. The police brutality towards the transvestite world of that time reminds us from where The Cross has journeyed. Elizabeth Burton, one of the most glamorous burlesque artists of the 1970s and also a personal

\footnotetext{
${ }^{21}$ See "Piccolo Tales 2016” from http://www.eventbrite.com.au/e/piccolo-tales-tickets-19614863585.

22 Elissa Blake (29 Jan. 2015), "Piccolo Tales Charts the Ever-Changing Face of the Cross”, Sydney Morning Herald, Entertainment, from http://www.smh.com.au/entertainment/theatre/piccolo-tales-charts-the-everchanging-face-of-the-cross-20150201-130sgq.html ${ }^{23}$ See Piccolo Tales 2015 programme; See also “A Heart Attack Fails to Stop Cafe Owner, 80” Daily Telegraph (28 Oct. 2014) from

http://www.dailytelegraph.com.au/lifestyle/food/sydney-taste/a-heart-attack-fails-to-stop-cafe-owner-80/news-story/2ddabca72e1 c058795db00e43e5cfae3; Elissa Blake, "Piccolo Tales Charts the Ever-Changing Face of the Cross".

${ }^{24}$ Interview Vashti Hughes 29 Jan. 2016. The characters listed are as stated by Hughes.
} 
friend of Vittorio's appears. A teenage American soldier on R \& R from the Vietnam War ends this decade of the 70s with understandable pathos. The heroin and other drugs flooding the Cross as a result of the war create the 1980s main character, a seedy heroin-crazed punk, perhaps prostitute. The AIDs epidemic takes its toll with Vittorio's heart-rending monologue about a missing beautiful young postman, Raphael, who Vittorio admired, adding to a sense of Vittorio's difference from the average cafe patron. A strip-club spruiker prompts us that strip clubs are no longer flanking the main streets of the Cross. In the 1990s decade we meet an eccy dealing Pommie DJ rapping about his good times. As we move into the 2000s the zeitgeist of the Cross begins to change. Hughes performs a gym junky, and the introduction of ice in the scene. Nostalgia oozes as we are taken on a tour of the signed photographs on the walls. The 2010s take us to Prue, one of the pram mafia, a yummy mummy. Vittorio bursts into a ranting song of "Fuck Off", covering all the annoying types that he despises. Finally Hughes parades as a gay guy who is always on his Grinder app. Intertwined through the parade of characters is the story of Bianchi's life, his relationship with his sister who worked alongside him in the cafe and her eventual death, and more shockingly the story of his rape in Naples by a soldier after the Second World War.

The kaleidoscope of characters offers more than simple amusement. Although Piccolo Tales is no re-enactment of history, it is a documentary through which the experience of being in the place and in the presence of Bianchi is able to phenomenologically evoke memories of the past. This is particularly so for audience members who were party to the years it represents. There is a sense of yearning that lingers when the show ends. Hughes discloses that there are patrons left crying at the show's finish and others who want to tell of their involvement in those years and scenes. Beyond that, Piccolo Tales evokes a desire for a certainty in local identity to be once more possible.

\section{The Actor as Signpost in Site-Specific Theatre}

Phil Smith, ${ }^{25}$ a British Performance Studies academic and practitioner has reconsidered the role of performers within site-specific work, in search of a model that leads beyond constructs of acting in these performances in terms of psychological realism or anti-realism. Coming from a sustained background with the well-respected site-specific research alliance, Wrights \& Sites $^{26}$, Smith is determined that the immediacy of the environment in any site-specific performance is foregrounded in any analysis of the work. His concept is that actors in site-specific productions can be viewed as signposts, or guides, pointing the audience as well as the performer towards the site, in an already meaning imbued environment (Smith, 2009, p. 161). This meaning is received by the audience through corporeal sensations, and resides in the present. Smith is concerned that a narrative viewing of the actor's role in site-specific work can act as a "voice of closure” (Smith, 2009, p. 159), whereas as a signpost the performance may be viewed as "servicing the site, pointing away from themselves, away from an 'inner life', to the surface” (Smith, 2009, p. 161). In the cases of the two site-specific productions under consideration in this paper, as an audience member at each production, the impact of my corporality with each site definitely defined my relationship with the productions. In Blood on the Southern Cross, the voice of the narrator was more of a signpost to the experience of the site than a performance. Eureka has a meaning to me in terms of that environs, on that evening, in that place, rather than as a set of historical facts. The

\footnotetext{
${ }^{25}$ See Phil Smith (2009), Actors as Signposts: A Model for Site-based and Ambulatory Performances, New Theatre Quarterly, 25(2), 159-171.

${ }^{26}$ See "Site-Specific: The Quay Thing Documented”, Studies in Theatre and Performance, Supplement No. 5 (August 2000).
} 
production although carrying cultural heritage was not confined to a "heritage interpretation" (Smith, 2009, p. 159), but instead, a living, active, set of meanings encountered in the moments of my presence there. Concomitantly in Piccolo Tales, Bianchi in particular drew the audience away from himself as a character in the performance and instead drew us in the present to the materiality of his cafe. He was, himself, a signpost or interface with a space that was both corporeal and cultural. He wasn't acting, instead his presence impacted on audiences carrying with it his decades within the immediate space. The perceptions engendered by his frail but feisty presence directed the audience to the now, the tiny cafe, the coffee bar, the myriad of signed photographs on the walls, his kitchen and the windows through which he has watched decades of Kings Cross characters pass by. For such a small, relatively unfunded show, it is this heightened, immediate and vivid encounter with space, both corporeal via the presence of Bianchi and cultural through the cafe, the pavement and the parkin which the performance unfolds, which I believe has garnered the responses that Piccolo Tales received.

\section{Conclusion}

This paper has aimed at investigating how cultural heritage has been embodied through two contrasting site-specific performances, Blood on the Southern Cross and Piccolo Tales. The instant, vivid sensations that site-specific performances offer have the ability to emblematise concepts of place ${ }^{27}$, in this case the place of Eureka in Blood on the Southern Cross and in Piccolo Tales, the place of Kings Cross. However beyond that, Rebecca Schneider's text, Performing Remains: Art and War in Times of Theatrical Reenactments, offers new ways of understanding how the past can be carried into the future performatively in site-specific work. Rather than simply reiterating events and knowledge, the embodied acts in performances, even when documenting or replicating cultural heritage events, create an immediate and transitory environment that can challenge audiences towards new routes or pathways of understanding. The liveness of any site circumvents closed readings of what is encountered. Rather than meeting "heritage" presentations, the two site-specific performances here suggest that what is past has not completely disappeared, or been lost. Instead history reasserts itself through the present, in the site, disrupting fixed concepts of time and space. In both productions, the multiple meanings of the performances and the sites intermingle. At times they compromise each other, for example the narrative voice in Blood on the Southern Cross, which sounds perfunctory and factual stands at odds with the witnessed goldfields, which appear chaotic, wild and passionate; the restrictive space of the Piccolo Bar in Piccolo Tales stands in contrast to the huge heartfelt life of the proprietor, Bianchi. At other times the performances and the site complement the intentions of the two pieces, one as an interpretation of Australian history and the other as a celebration of place. Whether compromising or complementing, fragmenting or unifying, the power of site-specific performance cannot be denied, offering multiple and engrossing affective experiences and resonances through the juxtaposition of work and site.

\section{References}

Ballarat, Victoria's goldfields: Official visitor guide. (2016). Ballarat: Ballarat Tourism. Retrieved from http://www.visitballarat.com.au

Blake, E. (2015, January 29). “Piccolo Tales charts the ever-changing face of the cross”. Sydney Morning Herald, Entertainment. Retrieved from

http://www.smh.com.au/entertainment/theatre/piccolo-tales-charts-the-everchanging-face-of-the-cross-20150201-130sgq.html

27 See Hayes (2012), “An Issue of Place”; Hayes (2013), “Reframing Tradition”. 
Blake, J. (2015, February 20). "Revue: Piccolo Tales set in the heart of its inspiration”. Sydney Morning Herald. Retrieved from http://www.smh.com.au/entertainment/theatre/review-piccolo-tales-set-in-the-heart-of-its-inspiration-20150220-13kkad.html

Cahir, F. (2012). Black gold: Aboriginal people on the goldfields of Victoria 1850-1870. Canberra: ANU Press.

Cohen, M. (2007). Tracing new absence: Events for place-making and place-faking. About Performance, 7, 189.

Cotter, R. (2016, March 18). “Review, Sydney: Piccolo Tales/Vashti Hughes”. Australian Stage. Retrieved from http://www.australianstage.com.au/201603177690/reviews/sydney/piccolo-tales-\%7C-vashti-hughes.html

Harvie, J. (2005). Staging the UK. Manchester: Manchester University Press.

Hayes, J. (2012). An issue of "place”: Circus WOW, women of Wollongong’s community circus. In G. Arrighi and V. Emeljanow (Eds.), A world of popular entertainments: An edited volume of critical essays (pp. 163-175). Newcastle, U.K.: Cambridge Scholars Press.

Hayes, J. (2013). Reframing tradition: Le Quy Duong’s festival theatre. Popular Entertainments Studies, 4(1), 95-109.

Kaye, N. (2000). Site-specific art: Performance, place and documentation. London: Routledge.

Knox, B. A. (2012). "Sir Charles Hotham (1806-1855)”. Australian Dictionary of Biography, National Centre of Biography, Australian National University. Retrieved from http://adb.anu.edu.au/biography/hotham-sir-charles-3803/text6027

Kwon, M. (2002). One place after another: Site-specific art and locational identity. Cambridge, MA: MIT Press.

McAuley, G. (2006). Unstable ground: Performance and the politics of place. Brussels: Peter Lang.

McAuley, G. (2007). Local acts: Site-specific performance practice, introduction. About Performance, 7, 7-11.

Pearson, M. (2010). Site-specific performance. Basingstoke, Hampshire: Palgrave Macmillan.

Pearson, M. (2012). Staging “The Persians” with the British army. In J. Tompkins and A. Birch (Eds.), Performing site-specific theatre: Politics, place, practice (p. 70). Basingstoke, Hampshire: Plagrave Macmillon.

Piccolo Tales 2016. (2016). Retrieved from http://www.eventbrite.com.au/e/piccolo-tales-tickets-19614863585

Roach, J. (1985). The player's passion: Studies in the science of acting. London: Associated University Presses.

Schneider, R. (2011). Performing remains: Art and war in times of theatrical reenactments. London and New York: Routledge.

Scott, I. (2014). “The Chinese in Ballarat”. Chinese National Heritage Interest. Retrieved from http://chinese-heritage.tripod.com/Chinese\%20in\%20Ballarat.htm

Sikora, N. (2003, July 6). New flames fan the Eureka rebellion. Sunday Herald Sun, 15.

Smith, P. (2009). Actors as signposts: A model for site-based and ambulatory performances. New Theatre Quarterly, 25(2), 159-171.

Soule, L., \& Thomson, P. (2000 August). Site-specific: The Quay Thing Documented. Studies in Theatre and Performance, Supplement, (5).

Sovereign Hill Victoria’s Most Valuable Tourist Icon. (2003).

Retrieved from http://www.premier.vic.gov.au/sovereign-hill-victoria’s-most-valuable-tourist-icon.

Tompkins, J., \& Birch, A. (Eds.). (2012). Performing site-specific theatre: Politics, place, practice. Basingstoke, Hampshire: Palgrave Macmillan.

Turner, C. (2004). Palimpsest or potential space? Finding a vocabulary for site-specific performance. New Theatre Quarterly, 20(4), 373-390.

Turner, I. (2012). "Peter Lalor (1827-1889)”. Australian Dictionary of Biography, National Centre of Biography, Australian National University. Retrieved from http://adp.anu.edu.au/biography/lalor-peter-3980/text6289

Weston, B. (2012). “Robert William Rede (1815-1904)”. Australian Dictionary of Biography, National Centre of Biography, Australian National University. Retrieved from http://adb.anu.edu.au/biography/rede-robert-william-4457/text7263

Wilkie, F. (2002). Mapping the terrain: A survey of site-specific performance in Britain. New Theatre Quarterly, 18(2), 140-160. 